\title{
Wodna dyspersja bezpostaciowej krzemionki jako dodatek poprawiający parametry technologiczne zaczynu cementowego
}

W celu uzyskania wymaganych parametrów technologicznych zarówno świeżego (płynnego), jak i stwardniałego zaczynu cementowego projektowane receptury poddawane są ciągłym modyfikacjom. Obecne w składzie zaczynu dodatki i domieszki wywierają wpływ na jego poszczególne właściwości, jednak zdarza się, że poprawa jednego parametru skutkować może jednocześnie pogorszeniem innego. Należy tak dobierać stosowane środki, aby w miarę możliwości uzyskać wymagane wartości konkretnych parametrów przy jednoczesnym zachowaniu na stałym (niezmiennym) poziomie pozostałych cech technologicznych zaczynu cementowego. Zdarza się, iż w trakcie prowadzenia prac badawczych uzyskuje się wyniki, które pozwalają stwierdzić, że stosowany dodatek powoduje poprawę wielu parametrów technologicznych zaczynu cementowego, co zostało omówione w niniejszym artykule. W trakcie realizacji prac badawczych wykazano korzystny wpływ dodatku wodnej dyspersji bezpostaciowej krzemionki na parametry świeżego i stwardniałego zaczynu cementowego i zastosowano dodatek szkła wodnego sodowego CB75 w określonej ilości w stosunku do ilości wody zarobowej. W celu potwierdzenia poprawy badanych parametrów technologicznych sporządzono kontrolne receptury zaczynów. Określone zostały takie własności zaczynu jak: parametry reologiczne, filtracja, czas gęstnienia, odstój wody, stabilność sedymentacyjna. Dla próbek stwardniałych zaczynów ustalono wpływ dodatku CB75 na parametry mechaniczne (wytrzymałość na ściskanie), parametry fizykomechaniczne (przyczepność do rur stalowych i przyczepność do formacji skalnej). Ponadto stwardniały zaczyn cementowy poddano analizom opisującym mikrostrukturę próbki i wykonano badania porowatości oraz przepuszczalności. W celu potwierdzenia poprawy parametrów świeżego i stwardniałego zaczynu badania przeprowadzone zostały dla receptur przeznaczonych do uszczelniania otworów $\mathrm{w}$ warunkach otworowych $\mathrm{w}$ temperaturze od $30^{\circ} \mathrm{C}$ do $90^{\circ} \mathrm{C}$ oraz przy ciśnieniu od $5 \mathrm{MPa}$ do $35 \mathrm{MPa}$.

Słowa kluczowe: wodna dyspersja bezpostaciowej krzemionki, krzemionka, szkło wodne sodowe, parametry technologiczne zaczynu cementowego, sedymentacja, stabilność sedymentacyjna.

\section{Aqueous dispersion of amorphous silica, as an additive improving the technological parameters of cement slurry}

In order to obtain the required technological parameters of both fresh (liquid) and hardened cement slurry, the designed recipes are subjected to constant modifications. The additives and admixtures present in the cement slurries formulas affect the various parameters of cement slurry, however, it may happen that the improvement of a given parameter can result in the deterioration of another parameter. The additives should be selected so that, where possible, the required values of the specific parameters will be achieved while maintaining at the constant (unchanging) level the other technological characteristics of the cement slurry. It is sometimes the case that during the implementation of the research, obtained results show that the additive used improves many of the technological parameters of the cement slurry, as discussed in this article. During the research work, the beneficial effects of the addition of an aqueous dispersion of amorphous silica on the parameters of fresh and set cement slurry have been shown. The CB75 water glass was added in a specific quantity in relation to the amount of water used. In order to confirm the improvement of the tested technological parameters, base cement slurries were prepared. The properties of the cement slurry such as: theological parameters, fluid loss, thickening time, free water and sedimentation stability were determined. For samples of hardened cement slurry, the effect of the CB75 addition on the mechanical parameters (compressive strength), physico-mechaical parameters (adhesion to steel pipes and adhesion to rock formation) were determined. In addition, the set cement slurry was subjected to microstructure analysis and porosity and permeability tests were also performed. In order to confirm the improvement of the parameters of fresh and hardened 
cement slurry, tests were conducted for cement slurries designed to seal wells under hole conditions of $30^{\circ} \mathrm{C}$ to $90^{\circ} \mathrm{C}$ and pressure from $5 \mathrm{MPa}$ to $35 \mathrm{MPa}$.

Key words: water dispersion of amorphous silica, Silica, water glass soda, technological parameters of the cement slurry, sedimentation, sedimentation stability.

\section{Wprowadzenie}

W celu uzyskania odpowiedniej szczelności płaszcza cementowego powstałego wskutek wiązania zaczynu uszczelniającego w przestrzeni pierścieniowej konieczne jest zaprojektowanie receptury spełniającej określone wymagania dla danych warunków geologiczno-technicznych. Uzależnione jest to od wielu czynników: liczby zapuszczanych kolumn rur okładzinowych, temperatury oraz ciśnienia, parametrów geologicznych, ale przede wszystkim od konstrukcji i przeznaczenia otworu wiertniczego. Zaczyny przeznaczone do uszczelniania otworów wiertniczych powinny posiadać odpowiednie własności technologiczne, takie jak: gęstość, filtracja, brak skurczu w trakcie hydratacji, a od powstałego z takiego zaczynu płaszcza cementowego wymaga się, aby wykazywał właściwe parametry mechaniczne i jak najniższą wartość przepuszczalności dla gazu. Ponadto podczas projek- towania zaczynów przeznaczonych do uszczelniania otworów kierunkowych i poziomych należy przestrzegać dodatkowych reżimów dotyczących parametrów świeżych zaczynów. Chodzi głównie o takie cechy jak: stabilność sedymentacyjna, odstój wody oraz filtracja zaczynu. W przypadku zaczynów przeznaczonych do uszczelniania otworów kierunkowych są to najważniejsze parametry decydujące o możliwości zastosowania zaczynu w tego typu otworach $[1,2,10$, 15, 20, 21, 23]. Podczas projektowania receptury zaczynu cementowego przeznaczonego dla konkretnego otworu wiertniczego bardzo często modyfikuje się jego skład, aby poprawić parametry technologiczne zaczynu lub uzyskać ich wymagane wartości. W tym celu stosowane są różnego rodzaju dodatki i domieszki do zaczynów cementowych w ilościach określonych podczas badań laboratoryjnych.

\section{Wpływ dodatków i domieszek na parametry technologiczne zaczynów cementowych}

Podczas opracowywania receptury zaczynu wykonywane są modyfikacje przy użyciu różnego rodzaju dodatków i domieszek w celu umożliwienia zastosowania danego składu do uszczelniania otworów wiertniczych. Prace badawcze prowadzone są w celu opracowania zaczynu, który będzie się charakteryzował:

- odpowiednią przetłaczalnością w czasie tłoczenia w przestrzeń pierścieniową. Należy doliczyć margines bezpieczeństwa do czasu tłoczenia. Jest on uzależniony od głębokości otworu i parametrów geologiczno-technicznych $[7,11,22]$;

- uzyskaniem czasu początku wiązania po wtłoczeniu do przestrzeni pierścieniowej. Jest to czas od momentu wytłoczenia płynnego zaczynu cementowego w wypełnianą przestrzeń pierścieniową do chwili, w której przechodzi on w fazę stałą, uzyskując zdolność szczelnego wypełnienia przestrzeni pierścieniowej. Czas ten powinien być możliwie krótki $[6,7,11,22]$;

- odpowiednimi wartościami parametrów reologicznych, które pozwolą na skuteczne wyparcie płuczki i cieczy buforowej z otworu przy zachowaniu minimalnych oporów przepływu. Zaczyny tego rodzaju powinny umożliwiać uzyskanie jak największego promienia wypełnienia uszczelnianego ośrodka;
- odpowiednią stabilnością sedymentacyjną, zerowym odstojem wody oraz filtracją $w$ warunkach otworopodobnych o wartości niższej niż $50 \mathrm{~cm}^{3} / 30$ minut $[5,9,13,19,21]$. Natomiast uzyskany z zaczynu płaszcz cementowy powinien wykazywać następujące cechy:

- zapewnić odpowiednią izolację międzystrefową (po związaniu posiadać wysokie wartości przyczepności na kontakcie z kolumną rur okładzinowych oraz z formacją skalną), - posiadać jak najmniejsze wartości przepuszczalności dla gazu oraz porowatości,

- wykazywać wysoką wartość wytrzymałości na ściskanie w temperaturze i przy ciśnieniu odpowiadającym uszczelnianemu interwałowi,

- zapewnić izolację kolumny rur przed niszczącym działaniem cieczy wiertniczych, a także przed zgnieceniem spowodowanym przez pęcznienie formacji skalnych,

- posiadać właściwości ekspansywne (nie powinien zmniejszać objętości podczas hydratacji) [3, 4, 12, 14, 16, 19];

Podczas projektowania receptury zaczynu najczęściej wykorzystuje się polimerowe środki modyfikujące parametry zaczynu oraz dodatki i domieszki mineralne o różnych frakcjach uziarnienia. Stosowanie ich ma na celu regulację parametrów zaczynu oraz doszczelnienie mikrostruktury tworzącego się płaszcza cementowego. Oprócz standardowych 
dodatków wpływających na (zgodną z oczekiwaniami) zmianę parametrów technologicznych zaczynu cementowego, tj. gęstość, filtrację, odstój wody oraz czas gęstnienia, stosuje się dodatki poprawiające parametry mechaniczne płaszcza cementowego. Dodatki tego rodzaju minimalizują, a niekiedy uniemożliwiają powstawanie mikroprzepływów gazu przez strukturę stwardniałego zaczynu cementowego. Dzieje się tak wskutek rozlokowania mikroziaren materiału drobnoziarnistego pomiędzy hydratyzującymi ziarnami klinkieru cementowego i wzrostu lepkości fazy ciekłej w miarę powstawania hydratów $[8,18]$. Najczęściej stosowanym w branży wiertniczej pucolanowym dodatkiem drobnoziarnistym jest krzemian sodu w postaci drobno zmielonej mączki krzemionkowej lub mikrokrzemionki. Krzemiany na skutek reakcji z jonami wapnia w cemencie lub z chlorkiem wapnia tworzą żel wapniowo-krzemianowy. Struktura tego żelu powoduje wzrost lepkości przy mieszaniu spoiwa z dużą ilością wody. Korzystną cechą materiałów krzemianowych jest to, iż nie powodują one efektu ubocznego w postaci absorbowania wody z zaczynu - jak ma to miejsce w przypadku np. drobnoziarnistych frakcji ilastych. Należy jednak wspomnieć, że stosowanie dodatków drobnoziarnistych okupione jest niekiedy problemem frakcjonowania ziaren w wodzie zarobowej (sedymentacja fazy stałej). Jednakże w przypadku krzemianu sodu jest możliwość zastosowania tego dodatku w postaci wodnej dyspersji potocznie nazywanej szkłem wodnym sodowym, które jest roztworem krzemionki otrzymywanym na drodze syntezy. Jest to ciecz o gęstości $1,23 \mathrm{~g} / \mathrm{cm}^{3}$ zawierająca rozdrobnione frakcje tlenku krzemu o bardzo rozwiniętej powierzchni właściwej. Dzięki tej powierzchni mikrokrzemionka działa stabilizująco w zaczynach cementowych, zmniejszając skłonność do sedymentacji poprzez swoje właściwości zagęszczające i tiksotropowe. Dodatkowo szybko wchodzi ona $\mathrm{w}$ reakcję $\mathrm{z}$ wolnym tlenkiem wapnia, poprawiając stopień związania kamienia cementowego. Struktura żelu wapniowo-krzemianowego powoduje wyraźny wzrost lepkości przy mieszaniu z dużą ilością wody, bez ubocznego efektu wydzielania wody wolnej z zaczynu cementowego. Powyższa cecha jest bardzo korzystna przy projektowaniu zaczynów o wysokiej stabilności sedymentacyjnej. Należy pamiętać, iż wodny roztwór krzemianu sodu $\mathrm{Na}_{2} \mathrm{O} \times(3-5) \mathrm{SiO}_{2}$ (szkło wodne) trzeba dodawać do wody zarobowej przed mieszaniem zaczynu cementowego; przy stosowaniu wraz $\mathrm{z} \mathrm{CaCl}{ }_{2}$, należy najpierw rozpuścić chlorek wapnia w wodzie i dopiero wówczas dozować pozostałe składniki w celu uzyskania optymalnych efektów [17].

Podczas projektowania zaczynów o wymaganej stabilności sedymentacyjnej coraz częściej proponuje się stosowanie dodatku szkła wodnego sodowego, z powodu jego właściwości. Biorąc powyższe pod uwagę, zrealizowane zostały prace badawcze nad poprawą parametrów technologicznych zaczynu cementowego wskutek zastosowania $\mathrm{Na}_{2} \mathrm{O} \times(3-5) \mathrm{SiO}_{2}$, a uzyskane wyniki przedstawiono w dalszej części artykułu.

\section{Przebieg prac badawczych}

Badania mające na celu określenie wpływu wodnej dyspersji bezpostaciowej krzemionki na poprawę parametrów technologicznych zaczynów cementowych były wykonywane w Laboratorium Zaczynów Uszczelniających INiG - PIB w oparciu o normy: PN-85/G-02320 Cementy $i$ zaczyny cementowe do cementowania $w$ otworach wiertniczych; PN-EN 10426-2 Przemyst naftowy i gazowniczy. Cementy i materialy do cementowania otworów. Część 2: Badania cementów wiertniczych oraz API SPEC 10 Specification for materials and testing for well cements.

Przedstawione poniżej wyniki prac badawczych zmierzały do potwierdzenia tezy, iż zastosowanie wodnej dyspersji bezpostaciowej krzemionki wpływa na poprawę wybranych parametrów technologicznych zaczynu cementowego. W tym celu badaniom poddano osiem składów zaczynów. Jako punkt odniesienia wykonano cztery receptury kontrolne. Zaczynami modyfikowanymi były cztery składy z dodatkiem szkła wodnego. W celu wychwycenia działania wodnej dyspersji bezpostaciowej krzemionki na parametry zaczynu w jak najszerszym zakresie warunków otwo- rowych, badania przeprowadzone zostały dla temperatur odpowiednio: $30^{\circ} \mathrm{C}, 50^{\circ} \mathrm{C}, 70^{\circ} \mathrm{C}$ i $90^{\circ} \mathrm{C}$, a także odpowiadających im ciśnień $5 \mathrm{MPa}, 18 \mathrm{MPa}, 25 \mathrm{MPa}$ i $35 \mathrm{MPa}$. Do badań wykorzystano szkło wodne sodowe o zakodowanej na potrzebę publikacji nazwie CB75, charakteryzujące się powierzchnią właściwą $750 \mathrm{~m}^{2} / \mathrm{g}$ i koncentracją masową krzemionki równą $15 \%$.

Spoiwem wiążącym użytym do sporządzenia zaczynów cementowych był cement wiertniczy G HSR. Wybór taki podyktowany był stosowaniem tej klasy cementu w warunkach przemysłowych. Podczas uszczelniania otworów o niewielkich głębokościach, z czym wiąże się niska temperatura i ciśnienie hydratacji zaczynu cementowego, stosuje się cement portlandzki klasy CEM I 32,5R. Jednak w tym cyklu badawczym wykorzystano we wszystkich recepturach cement G HSR w celu wyeliminowania rozbieżności wyników związanych z zastosowaniem różnych rodzajów spoiw w zależności od temperatury (od $30^{\circ} \mathrm{C}$ do $90^{\circ} \mathrm{C}$ ). $\mathrm{W}$ celu doszczelnienia matrycy płaszcza cementowego we wszystkich recepturach użyto dodatku mikrocementu w ilości 20\%. Przyjęto 
stały iloraz wodno-cementowy równy 0,50 ; jedynie receptura dla warunków otworowych o temperaturze $70^{\circ} \mathrm{C}$ i ciśnieniu $25 \mathrm{MPa}$ charakteryzowała się ilością wody o w/c =0,57. Składniki takie jak dodatek antyfiltracyjny i dodatek spęczniający zastosowano w stałych ilościach, wynoszących odpowiednio $0,2 \%$ bwoc oraz $0,3 \%$ bwoc (tablica 1 ). Użyto również stałych ilości lateksu (10\% bwoc) oraz stabilizatora lateksu (1\% bwoc). Zaczyny sporządzono na 3-procentowym zasoleniu (bwow ${ }^{1}$ ) wody zarobowej. Dodatki odpieniający, upłynniający, przyspieszający i opóźniający czas wiązania zastosowano $\mathrm{w}$ ilościach podanych w tablicy 1 . Zastosowano wodną dyspersję bezpostaciowej krzemionki (szkło wodne CB75) w stałej ilości 3,0\% (bwow). Odmierzoną ilość szkła wodnego dawkowano do wody zarobowej wraz z pozostałymi składnikami (oprócz cementu, który dozowano w ostatnim etapie sporządzania zaczynu).

Na podstawie przyjętych kryteriów dotyczących warunków otworopodobnych oraz proporcji mieszanin sporządzono cztery receptury kontrolne oraz opracowano cztery zaczyny zmodyfikowane dodatkiem szkła wodnego CB75. Wskutek takiej metodyki postępowania możliwe było określenie wpływu dodatku szkła wodnego sodowego na poprawę parametrów technologicznych zaczynów w danych warunkach. Dokładne ilości poszczególnych składników zestawiono w tablicy 1.

\footnotetext{
${ }^{1}$ Bwow $-\mathrm{w}$ stosunku do ilości wody (z ang. by weight of water).
}

Po zapoznaniu się z uzyskanymi wynikami przeprowadzonych badań stwierdzono, iż dodatek szkła wodnego sodowego spowodował nieznaczne obniżenie gęstości zaczynów w porównaniu z recepturami bazowymi (rysunek 1, tablica 2). Najmocniejsze obniżenie gęstości nastąpiło w zaczynie przeznaczonym do uszczelniania kolumny rur w temperaturze $30^{\circ} \mathrm{C}$ i przy ciśnieniu $5 \mathrm{MPa}$, gdzie spadek gęstości wynosił $35 \mathrm{~kg} / \mathrm{m}^{3}$ w porównaniu z zaczynem bazowym. W pozostałych składach redukcja gęstości zachowana była na stałym poziomie wynoszącym $20 \mathrm{~kg} / \mathrm{m}^{3}$. Zastosowanie szkła wodnego skutkowało poprawą stabilności sedymentacyjnej zaczynów $\mathrm{z}$ tym dodatkiem $\mathrm{w}$ porównaniu $\mathrm{z}$ zaczynami bazowymi. W tablicy 2 oraz na rysunku 2 zestawiono wartości gęstości w poszczególnych punktach pomiarowych podczas badania w kolumnie sedymentacyjnej (fotografia 1). W celu zobrazowania różnic gęstości w poszczególnych punktach pomiarowych na rysunku 3 przedstawiono wartości gęstości w kolumnie sedymentacyjnej. Zaczyny bazowe posiadały różnice gęstości pomiędzy górnym a środkowym oraz środkowym a dolnym punktem pomiaru w zakresie od $5 \mathrm{~kg} / \mathrm{m}^{3}$ do $15 \mathrm{~kg} / \mathrm{m}^{3}$ (rysunek 3). Natomiast po zastosowaniu dodatku szkła wodnego zaczyn wykazywał jednorodną strukturę, w której gęstość była jednakowa we wszystkich punktach pomiaru (górna, środkowa oraz dolna część kolumny pomiarowej).

Zastosowanie szkła wodnego powodowało zmniejszenie wartości rozlewności, a najmocniejszą redukcję tego parametru zaobserwowano w zaczynie o największym współczynniku

Tablica 1. Receptury zaczynów cementowych dla warunków otworowych.

Spoiwo wiążące: cement G HSR $=100 \%$, mikrocement 20,0\% (bwoc)

\begin{tabular}{|c|c|c|c|c|c|c|c|c|c|c|c|}
\hline $\begin{array}{c}\text { Skład }(\mathrm{Nr}) \\
\text { współczynnik } \\
(\mathrm{w} / \mathrm{c})\end{array}$ & 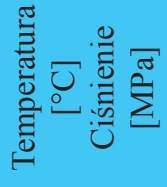 & 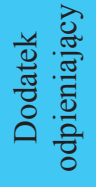 & 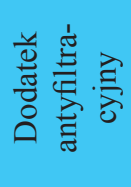 & 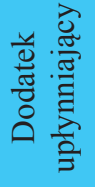 & 童 & 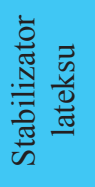 & $\begin{array}{l}\bar{y} \\
\bar{y} \\
\overline{1}\end{array}$ & 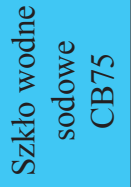 & 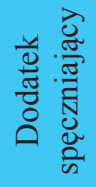 & $\vec{\mho}^{N}$ & 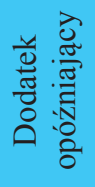 \\
\hline $\begin{array}{c}\mathrm{Nr} 1 \\
\mathrm{w} / \mathrm{c}=0,50\end{array}$ & \multirow{2}{*}{$\begin{array}{c}30^{\circ} \mathrm{C} \\
5 \mathrm{MPa}\end{array}$} & 0,3 & 0,20 & 0,20 & 10,0 & 1,0 & 3,0 & - & 0,3 & 4,0 & - \\
\hline $\begin{array}{c}\mathrm{Nr} 2 \\
\mathrm{w} / \mathrm{c}=0,50\end{array}$ & & 0,3 & 0,20 & 0,20 & 10,0 & 1,0 & 3,0 & 3,0 & 0,3 & 2,0 & - \\
\hline $\begin{array}{c}\mathrm{Nr} 3 \\
\mathrm{w} / \mathrm{c}=0,50\end{array}$ & \multirow{2}{*}{$\begin{array}{c}50^{\circ} \mathrm{C} \\
18 \mathrm{MPa}\end{array}$} & 0,3 & 0,20 & 0,15 & 10,0 & 1,0 & 3,0 & - & 0,3 & - & 0,10 \\
\hline $\begin{array}{c}\mathrm{Nr} 4 \\
\mathrm{w} / \mathrm{c}=0,50\end{array}$ & & 0,3 & 0,20 & 0,15 & 10,0 & 1,0 & 3,0 & 3,0 & 0,3 & - & 0,20 \\
\hline $\begin{array}{c}\mathrm{Nr} 5 \\
\mathrm{w} / \mathrm{c}=0,57\end{array}$ & \multirow{2}{*}{$\begin{array}{c}70^{\circ} \mathrm{C} \\
25 \mathrm{MPa}\end{array}$} & 0,4 & 0,20 & 0,20 & 10,0 & 1,0 & 3,0 & - & 0,3 & - & 0,30 \\
\hline $\begin{array}{c}\mathrm{Nr} 6 \\
\mathrm{w} / \mathrm{c}=0,57\end{array}$ & & 0,4 & 0,20 & 0,20 & 10,0 & 1,0 & 3,0 & 3,0 & 0,3 & - & 0,40 \\
\hline $\begin{array}{c}\mathrm{Nr} 7 \\
\mathrm{w} / \mathrm{c}=0,50\end{array}$ & \multirow{2}{*}{$\begin{array}{c}90^{\circ} \mathrm{C} \\
35 \mathrm{MPa}\end{array}$} & 0,5 & 0,20 & 0,25 & 10,0 & 1,0 & 3,0 & - & 0,3 & - & 0,25 \\
\hline $\begin{array}{c}\mathrm{Nr} 8 \\
\mathrm{w} / \mathrm{c}=0,50\end{array}$ & & 0,5 & 0,20 & 0,25 & 10,0 & 1,0 & 3,0 & 3,0 & 0,3 & - & 0,35 \\
\hline
\end{tabular}




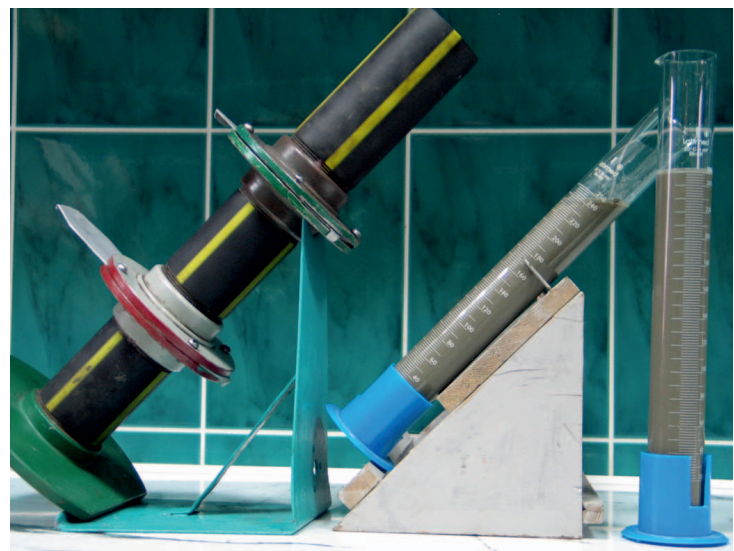

Fot. 1. Stanowisko do oznaczania stabilności sedymentacyjnej zaczynu cementowego i odstoju wody (po lewej - kolumna sedymentacyjna, po prawej - cylindry do pomiaru odstoju wody)

wodno-cementowym (zaczyn nr 6 w tablicy 2), w którym rozlewność wynosiła $225 \mathrm{~mm}$, natomiast w zaczynie kontrolnym dla tej receptury odnotowano rozlewność $290 \mathrm{~mm}$.

Porównując wartości odstoju wody, zauważono obniżenie tego parametru do wartości zerowej we wszystkich recepturach. Jedynie w zaczynie nr 6 zaobserwowano obniżenie ilości wody wolnej z wartości $0,2 \%$ w zaczynie bazowym do wartości $0,1 \%$ po zastosowaniu dodatku szkła wodnego. Osłabiony efekt redukcji wody wolnej w tym zaczynie może być wynikiem wyższego współczynnika wodno-cementowego w recepturze. Uzyskane wyniki zestawiono w tablicy 2 oraz przedstawiono na rysunku 1.
Podczas analizy wartości filtracji zaczynu widoczne było obniżenie tego parametru we wszystkich recepturach po zastosowaniu dodatku szkła wodnego sodowego. Zaobserwowano efekt nasilającego się obniżania filtracji na skutek użycia dodatku szkła wodnego wraz ze wzrostem temperatury pomiaru (tablica 2). Najmniejszą redukcję wartości filtracji uzyskano w zaczynie $\mathrm{nr} 2$ dla temperatury $30^{\circ} \mathrm{C}$, w którym redukcja filtracji wynosiła $21 \mathrm{~cm}^{3} / 30 \mathrm{~min}$ (z wartości bazowej $46 \mathrm{~cm}^{3} / 30 \mathrm{~min}$ do wartości $25 \mathrm{~cm}^{3} / 30$ min po zastosowaniu dodatku szkła wodnego). Natomiast najmocniejsze działanie antyfiltracyjne widoczne było w zaczynie $\mathrm{nr} 8$ przeznaczonym dla temperatury $90^{\circ} \mathrm{C}$, w którym uzyskano obniżenie wartości filtracji o $56 \mathrm{~cm}^{3} / 30 \mathrm{~min}$ (z wartości bazowej $82 \mathrm{~cm}^{3} / 30 \mathrm{~min}$ do wartości $26 \mathrm{~cm}^{3} / 30 \mathrm{~min}$ po zastosowaniu dodatku szkła wodnego).

Rozpatrując wpływ dodatku zastosowanego szkła wodnego na czas gęstnienia zaczynu cementowego, zaobserwowano skrócenie zarówno początku czasu gęstnienia wynoszącego $30 \mathrm{Bc}^{2}$, jak i końca czasu gęstnienia opisywanego wartością $100 \mathrm{Bc}$. Powyższy efekt uzyskano dla wszystkich zaczynów modyfikowanych dodatkiem szkła wodnego CB75. Otrzymane wyniki zestawiono w tablicy 2 oraz na rysunku 4.

Porównanie wartości parametrów reologicznych zestawiono w tablicy 3 oraz na rysunku 5 - w celu lepszego uwidocz-

\footnotetext{
${ }^{2} \mathrm{Bc}$ - jednostka czasu gęstnienia zaczynu cementowego podczas pomiaru w konsystometrze (jednostka Beardena).
}

Tablica 2. Parametry badanych zaczynów cementowych

\begin{tabular}{|c|c|c|c|c|c|c|c|c|c|c|c|c|c|c|c|c|c|}
\hline \multirow[t]{2}{*}{ 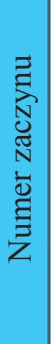 } & \multirow{2}{*}{ 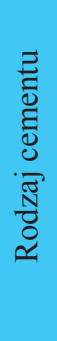 } & \multirow{2}{*}{ 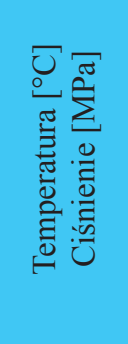 } & \multirow{2}{*}{ 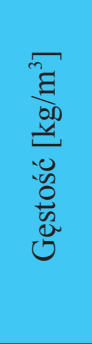 } & \multicolumn{3}{|c|}{ 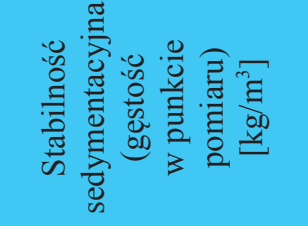 } & \multirow{2}{*}{ 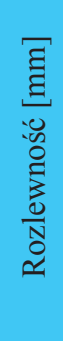 } & \multirow{2}{*}{$\begin{array}{l}\frac{0}{0} \\
2 \\
0 \\
0 \\
3 \\
0 \\
00 \\
0\end{array}$} & \multirow{2}{*}{ 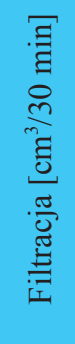 } & \multicolumn{2}{|c|}{ 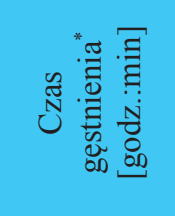 } & \multicolumn{6}{|c|}{$\begin{array}{l}\text { Odczyty z aparatu Fann } \\
\text { [j.f.* przy obr./min] }\end{array}$} \\
\hline & & & & góra & środek & dół & & & & $\begin{array}{l}30 \\
\mathrm{Bc}\end{array}$ & $\begin{array}{l}100 \\
\mathrm{Bc}\end{array}$ & 600 & 300 & 200 & 100 & 6 & 3 \\
\hline 1 & \multirow{8}{*}{$\underset{0}{\mathscr{A}}$} & \multirow{2}{*}{$\begin{array}{l}30^{\circ} \mathrm{C} \\
5 \mathrm{MPa}\end{array}$} & 1885 & 1880 & 1885 & 1890 & 245 & 0,3 & 46,0 & $4: 20$ & $4: 50$ & 190 & 107 & 78 & 45 & 14 & 10 \\
\hline 2 & & & 1850 & 1850 & 1850 & 1850 & 235 & 0,0 & 25,0 & $2: 20$ & $3: 00$ & 202 & 114 & 83 & 51 & 13 & 12 \\
\hline 3 & & \multirow{2}{*}{$\begin{array}{c}50^{\circ} \mathrm{C} \\
18 \mathrm{MPa}\end{array}$} & 1840 & 1830 & 1840 & 1850 & 215 & 0,2 & 56,0 & $3: 17$ & $3: 39$ & 207 & 119 & 89 & 55 & 16 & 14 \\
\hline 4 & & & 1820 & 1820 & 1820 & 1820 & 190 & 0,0 & 14,0 & $1: 50$ & $2: 06$ & 204 & 122 & 94 & 63 & 26 & 24 \\
\hline 5 & & \multirow{2}{*}{$\begin{array}{c}70^{\circ} \mathrm{C} \\
25 \mathrm{MPa}\end{array}$} & 1780 & 1765 & 1780 & 1795 & 290 & 0,2 & 70,0 & $4: 10$ & $4: 50$ & 131 & 70 & 49 & 27 & 3 & 2 \\
\hline 6 & & & 1760 & 1760 & 1760 & 1760 & 225 & 0,1 & 18,0 & 2:09 & $3: 40$ & 121 & 69 & 51 & 31 & 8 & 7 \\
\hline 7 & & \multirow{2}{*}{$\begin{array}{c}90^{\circ} \mathrm{C} \\
35 \mathrm{MPa}\end{array}$} & 1840 & 1835 & 1840 & 1845 & 265 & 0,1 & 82,0 & $6: 02$ & $6: 52$ & 216 & 120 & 85 & 49 & 6 & 4 \\
\hline 8 & & & 1820 & 1820 & 1820 & 1820 & 260 & 0,0 & 26,0 & $3: 30$ & $3: 40$ & 223 & 121 & 85 & 48 & 6 & 4 \\
\hline
\end{tabular}

Objaśnienie:

* Czas dojścia do temperatury: $30^{\circ} \mathrm{C}=10 \mathrm{~min}$,

$50^{\circ} \mathrm{C}=25 \min , 70^{\circ} \mathrm{C}=40 \min , 90^{\circ} \mathrm{C}=60 \min$

** j.f. - jednostki Fann 
Tablica 3. Parametry reologiczne zaczynów cementowych

\begin{tabular}{|c|c|c|c|c|c|c|c|c|c|}
\hline \multirow{2}{*}{$\begin{array}{l}\text { Model } \\
\text { reologiczny }\end{array}$} & \multirow{2}{*}{$\begin{array}{l}\text { Parametry } \\
\text { reologiczne }\end{array}$} & \multicolumn{8}{|c|}{ Zaczyn nr: } \\
\hline & & 1 & 2 & 3 & 4 & 5 & 6 & 7 & 8 \\
\hline \multirow{2}{*}{$\begin{array}{c}\text { Model } \\
\text { Newtona }\end{array}$} & Lepkość dynamiczna $[\mathrm{Pa} \cdot \mathrm{s}]$ & 0,0998 & 0,1063 & 0,1100 & 0,1106 & 0,0673 & 0,0640 & 0,1125 & 0,1152 \\
\hline & Współczynnik korelacji [-] & 0,9861 & 0,9845 & 0,9775 & 0,9421 & 0,9974 & 0,9826 & 0,9939 & 0,9961 \\
\hline \multirow{3}{*}{$\begin{array}{c}\text { Model } \\
\text { Binghama }\end{array}$} & Lepkość plastyczna $[\mathrm{Pa} \cdot \mathrm{s}]$ & 0,0899 & 0,0953 & 0,0966 & 0,0900 & 0,0647 & 0,0571 & 0,1063 & 0,1098 \\
\hline & Granica płynięcia $[\mathrm{Pa}]$ & 6,9568 & 7,7284 & 9,4213 & 14,5043 & 1,8117 & 4,8324 & 4,4093 & 3,8051 \\
\hline & Współczynnik korelacji [-] & 0,9985 & 0,9982 & 0,9973 & 0,9972 & 0,9990 & 0,9975 & 0,9975 & 0,9986 \\
\hline \multirow{3}{*}{$\begin{array}{c}\text { Model } \\
\text { Ostwalda de } \\
\text { Waele'a }\end{array}$} & Współczynnik konsystencji $\left[\mathrm{Pa} \cdot \mathrm{s}^{\mathrm{n}}\right]$ & 2,0184 & 2,1719 & 2,7547 & 5,6918 & 0,2593 & 1,2944 & 0,5591 & 0,5527 \\
\hline & Wykładnik potęgowy [-] & 0,5263 & 0,5256 & 0,4952 & 0,3838 & 0,7894 & 0,5285 & 0,7524 & 0,7556 \\
\hline & Współczynnik korelacji [-] & 0,9618 & 0,9646 & 0,9643 & 0,9465 & 0,9990 & 0,9689 & 0,9963 & 0,9938 \\
\hline \multirow{3}{*}{$\begin{array}{c}\text { Model } \\
\text { Cassona }\end{array}$} & Lepkość Cassona $[\mathrm{Pa} \cdot \mathrm{s}]$ & 0,0635 & 0,0675 & 0,0657 & 0,0504 & 0,0586 & 0,0407 & 0,0943 & 0,0972 \\
\hline & Granica płynięcia $[\mathrm{Pa}]$ & 2,9038 & 3,1676 & 4,1373 & 8,3111 & 0,2450 & 1,9321 & 0,6961 & 0,6183 \\
\hline & Współczynnik korelacji [-] & 0,9993 & 0,9997 & 0,9998 & 0,9988 & 0,9998 & 0,9999 & 0,9992 & 0,9998 \\
\hline \multirow{4}{*}{$\begin{array}{c}\text { Model } \\
\text { Herschela- } \\
\text { Bulkleya }\end{array}$} & Granica płynięcia $[\mathrm{Pa}]$ & 4,8629 & 5,1355 & 6,1903 & 11,4099 & 0,5304 & 2,9716 & 0,9597 & 1,1764 \\
\hline & Współczynnik konsystencji $\left[\mathrm{Pa} \cdot \mathrm{s}^{\mathrm{n}}\right]$ & 0,1914 & 0,2271 & 0,2734 & 0,2612 & 0,1242 & 0,1579 & 0,2929 & 0,2382 \\
\hline & Wykładnik potęgowy [-] & 0,8916 & 0,8755 & 0,8509 & 0,8473 & 0,9064 & 0,8543 & 0,8547 & 0,8888 \\
\hline & Współczynnik korelacji [-] & 0,9999 & 1,0000 & 1,0000 & 0,9999 & 1,0000 & 1,0000 & 1,0000 & 1,0000 \\
\hline
\end{tabular}

nienia zachodzących wskutek zastosowania wybranego dodatku zmian. Zauważalny jest wzrostowy trend granicy płynięcia opisywanej modelem Hershela-Bulkleya, przy czym najmocniejszy wzrost zaobserwowano dla zaczynów przeznaczonych do uszczelniania kolumn rur w temperaturach $50^{\circ} \mathrm{C} \mathrm{i} 70^{\circ} \mathrm{C}$. Analizując wyniki lepkości plastycznej Cassona, zauważono obniżenie wartości w przypadku zaczynów nr 4 i 6 opracowanych dla temperatur $50^{\circ} \mathrm{C}$ oraz $70^{\circ} \mathrm{C}$. Natomiast zaczyny nr 2 oraz 8 , przeznaczone do uszczelniania kolumn rur w temperaturach $30^{\circ} \mathrm{C}$ i $90^{\circ} \mathrm{C}$, wykazują nieznaczny wzrost lepkości Cassona po zastosowaniu dodatku szkła wodnego sodowego.

Podczas analizy wpływ dodatku szkła wodnego na poprawę parametrów mechanicznych stwardniałych zaczynów cementowych wykonane zostały badania wytrzymałości na ściskanie, przyczepności do formacji skalnej (wzorcowej próbki piaskowca) oraz przyczepności do rur stalowych. Dodatkowo przeprowadzono badania wpływu dodatku szkła wod- nego na przepuszczalność oraz porowatość próbki. Uzyskane wyniki badań zestawiono na rysunkach 6-9.

Analizując otrzymane wyniki zrealizowanych badań, zaobserwowano wzrost wytrzymałości na ściskanie po każdym z przyjętych czasów hydratacji próbek oraz we wszystkich warunkach otworopodobnych. Najmocniejszy wzrost wytrzymałości na ściskanie zauważono w przypadku receptur dla temperatur $50^{\circ} \mathrm{C}$ i $90^{\circ} \mathrm{C}$, natomiast nieco mniejszy

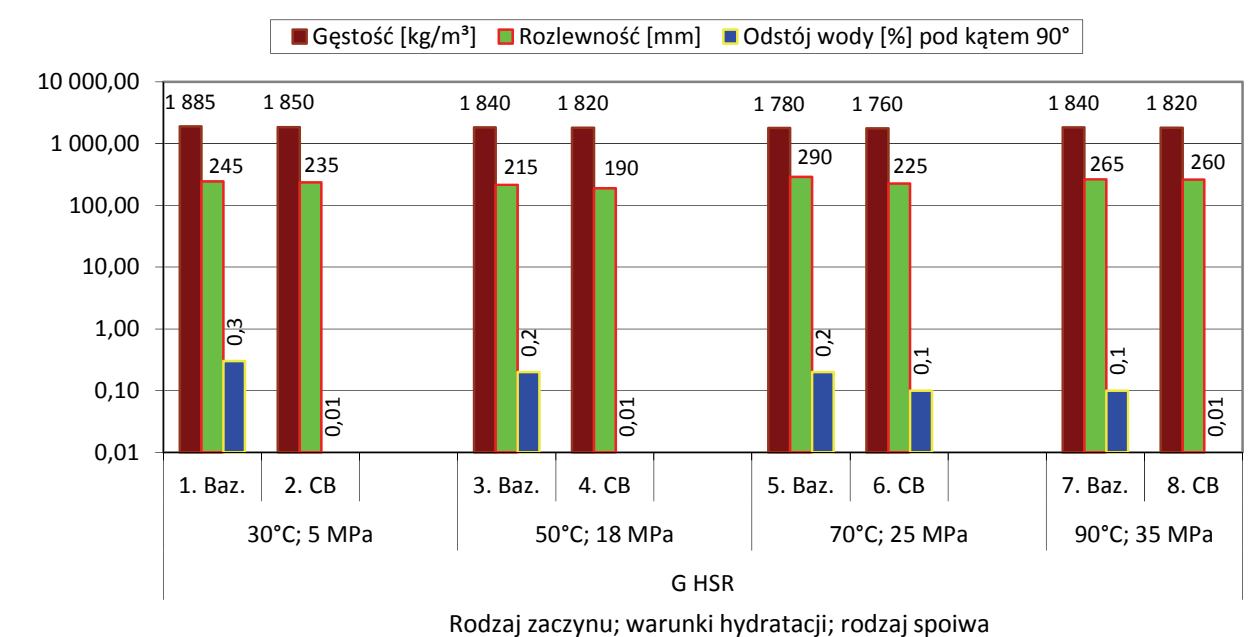

Rys. 1. Zestawienie wyników badań gęstości, rozlewności i odstoju wody świeżych zaczynów cementowych 
przyrost wartości widoczny był w temperaturach $30^{\circ} \mathrm{C}$ i $70^{\circ} \mathrm{C}$ (rysunek 6). Taki efekt może być tłumaczony wzrostem wytrzymałości wraz ze zwiększaniem się temperatury i ciśnienia hydratacji. Wzrastające ciśnienie powoduje zaciskanie mikronieszczelności podczas hydratacji zaczynu cementowego. Zgodnie $\mathrm{z}$ tą regułą zaczyn hydratyzujący w temperaturze $30^{\circ} \mathrm{C}$ i przy ciśnieniu $5 \mathrm{MPa}$ wykazuje mniej dynamiczny przyrost wytrzymałości niż zaczyn deponowany w temperaturze $50^{\circ} \mathrm{C}$ i przy ciśnieniu $18 \mathrm{MPa}$. Na rysunku 6 widoczny jest jednak mniej intensywny przyrost wytrzymałości w przypadku zaczynu przeznaczonego do uszczelniania kolumn rur w temperaturze $70^{\circ} \mathrm{C}$ i przy ciśnieniu $25 \mathrm{MPa}$. Niniejsze odstępstwo od wspomnianej dla tych zaczynów reguły może być wynikiem zastosowanego wyższego współczynnika wodno-cementowego w tej recepturze, który wynosił 0,57 (pozostałe zaczyny $\mathrm{w} / \mathrm{c}=0,50$ ). Większa ilość wody wiąże się z występowaniem wolnych przestrzeni w strukturze próbki, czego efektem jest niższa wytrzymałość i wolniejszy jej przyrost wraz z czasem hydratacji próbki.

Badania przyczepności do skały wykazały wzrost wartości przyczepności dla wszystkich zaczynów modyfikowanych dodatkiem szkła wodnego sodowego CB75 w porównaniu z ich zaczynami kontrolnymi (rysunek 7). Podobnie jak podczas badania wytrzymałości na ściskanie, również pomiar przyczepności do skały skutkował wyraźniejszym wzrostem badanych parametrów w czasie deponowania próbek $\mathrm{w}$ temperaturach $50^{\circ} \mathrm{C}$ i $90^{\circ} \mathrm{C}$. Zaobserwowano także poprawę przyczepności płaszcza cementowego do rur stalowych w przypadku zaczynów modyfikowanych dodatkiem szkła wodnego sodowego w porównaniu z próbkami bazowymi (rysunek 8). Przy czym najmocniejszy trend

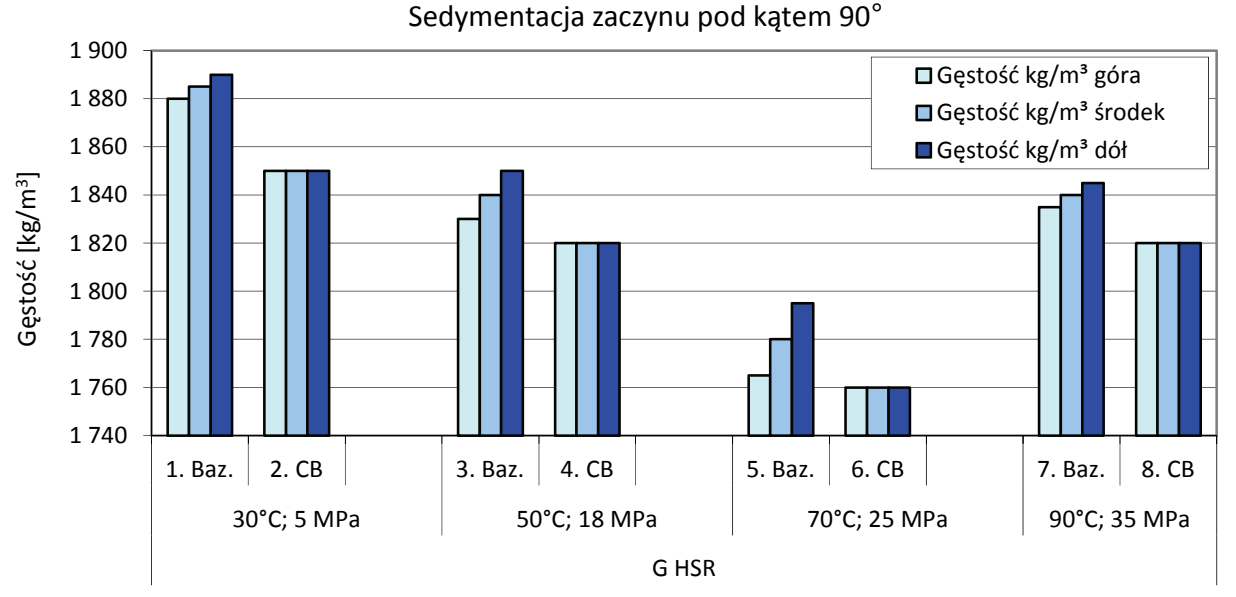

Rodzaj zaczynu; warunki hydratacji; rodzaj spoiwa

Rys. 2. Zestawienie gęstości zaczynu w poszczególnych punktach pomiarowych kolumny sedymentacyjnej

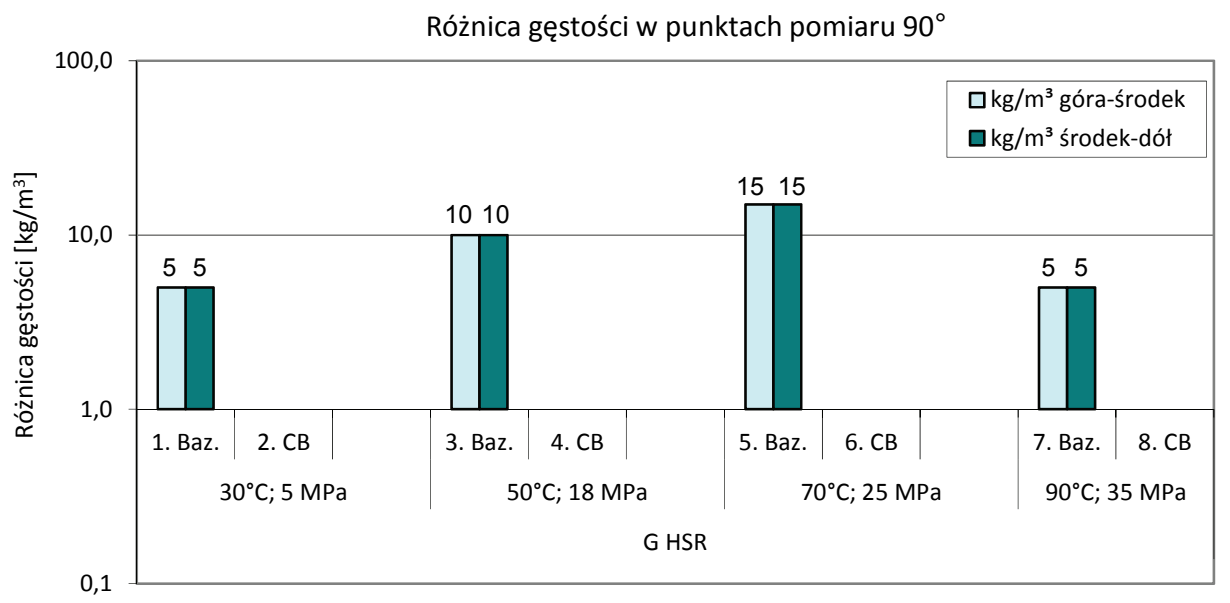

Rodzaj zaczynu; warunki hydratacji; rodzaj spoiwa

Rys. 3. Porównanie różnic gęstości w poszczególnych punktach pomiarowych kolumny sedymentacyjnej (różnica pomiędzy górną a środkową częścią oraz różnica pomiędzy środkową a dolną częścią kolumny)

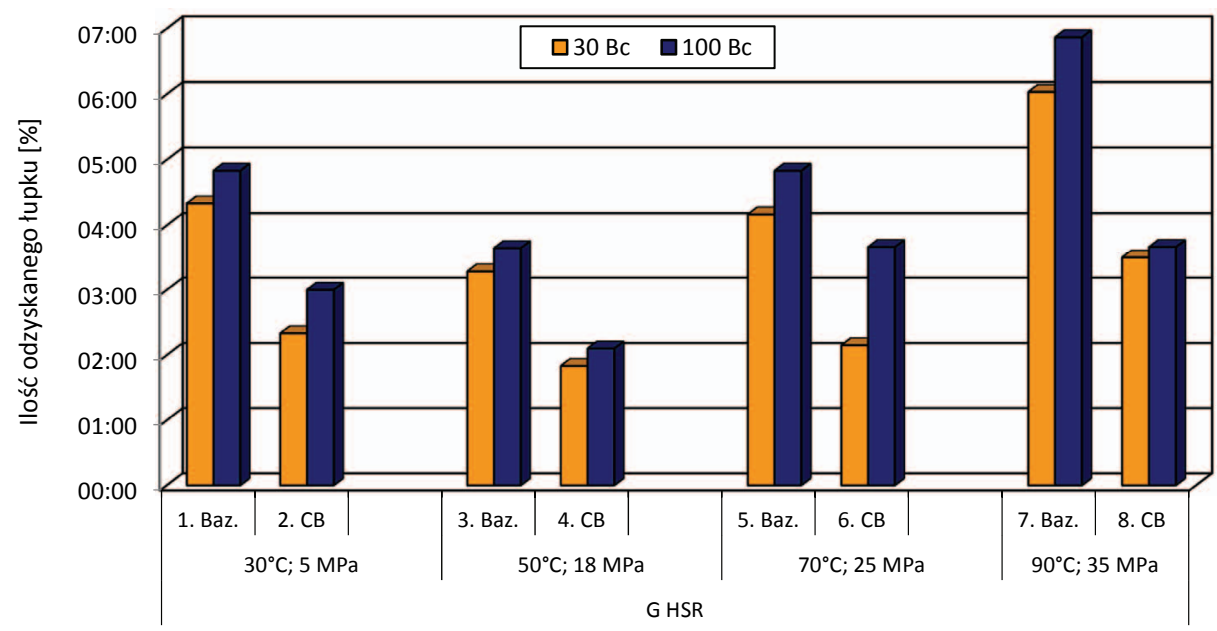

Rys. 4. Zestawienie pomiarów czasu gęstnienia zaczynów cementowych 
po czasie deponowania próbek równym 28 dni.

Zastosowanie dodatku szkła wodnego sodowego do receptury zaczynu skutkowało znacznym obniżeniem przepuszczalności dla gazu po 28 dniach hydratacji próbek oraz zmniejszeniem porowatości próbek (rysunek 9). Przy czym najmocniejsze obniżenie przepuszczalności i porowatości widoczne było w próbce deponowanej w temperaturze $90^{\circ} \mathrm{C}$ i przy ciśnieniu $35 \mathrm{MPa}$, co może mieć związek z doszczelniającym działaniem warunków hydratacji. Dodatek szkła wodnego sodowego wykazywał doszczelniające działanie dla projektowanego zaczynu cementowego, dzięki czemu możliwe jest ogra-

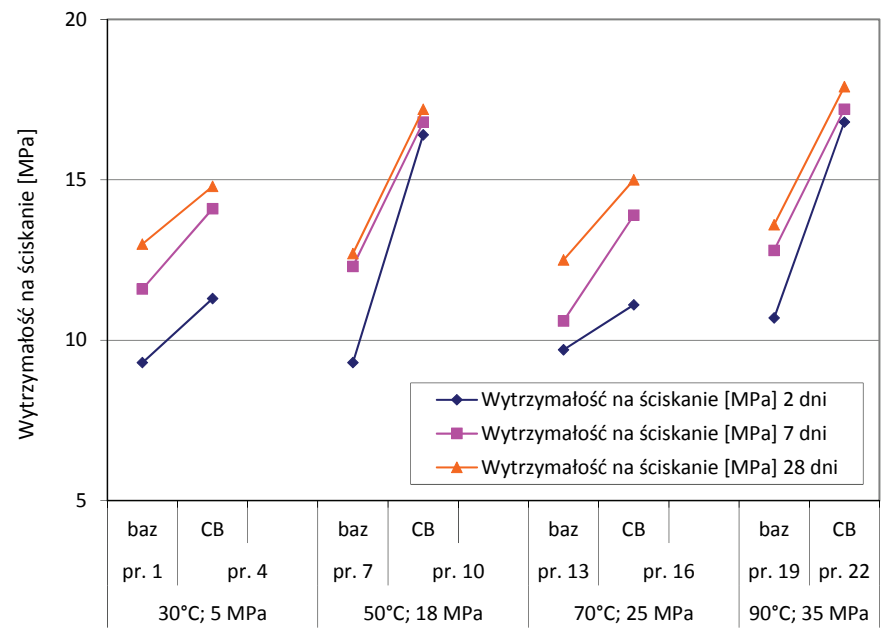

Rys. 6. Zestawienie wytrzymałości na ściskanie badanych próbek

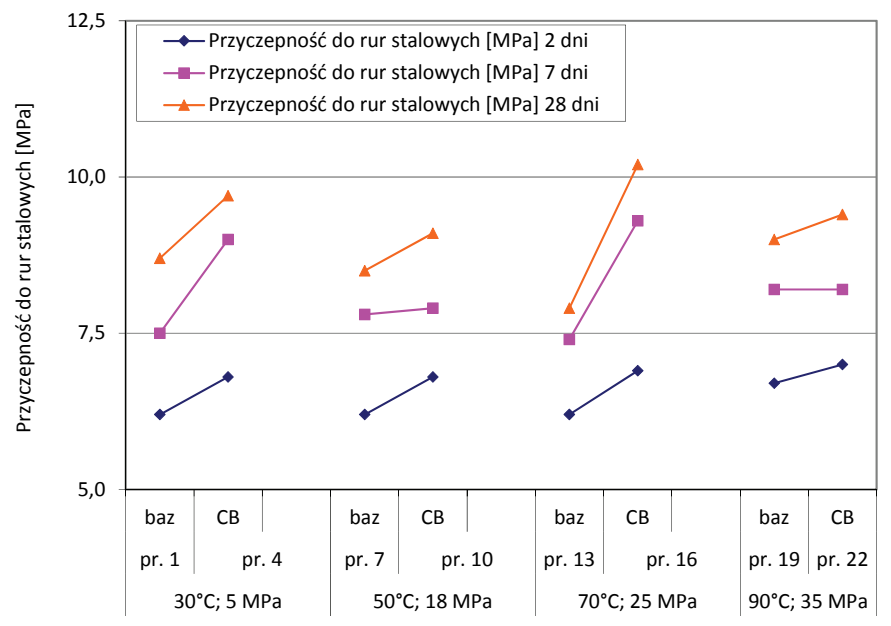

Rys. 8. Zestawienie przyczepności do rur stalowych badanych próbek niczenie występowania mikroprzepływów gazowych przez strukturę stwardniałego zaczynu cementowego.

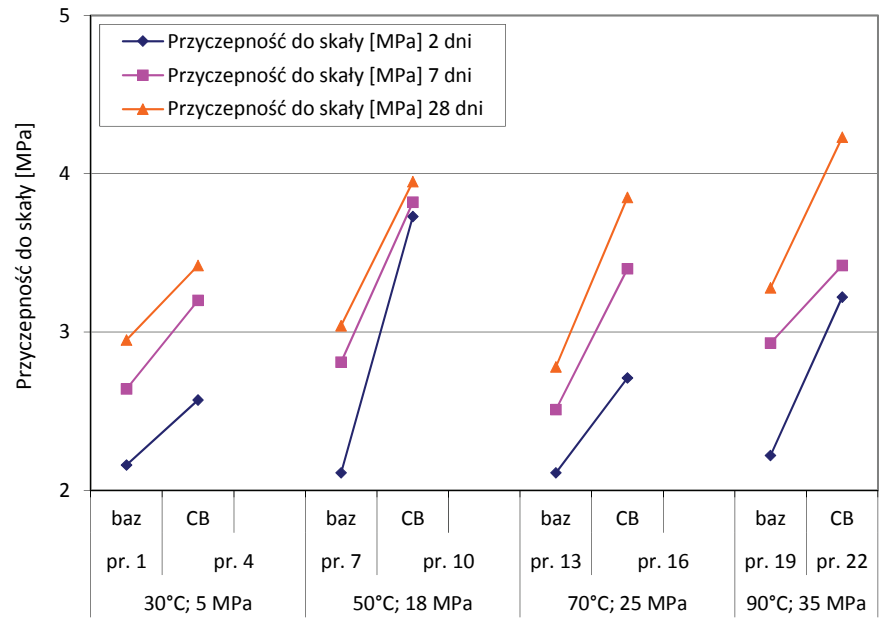

Rys. 7. Zestawienie przyczepności do skały badanych próbek

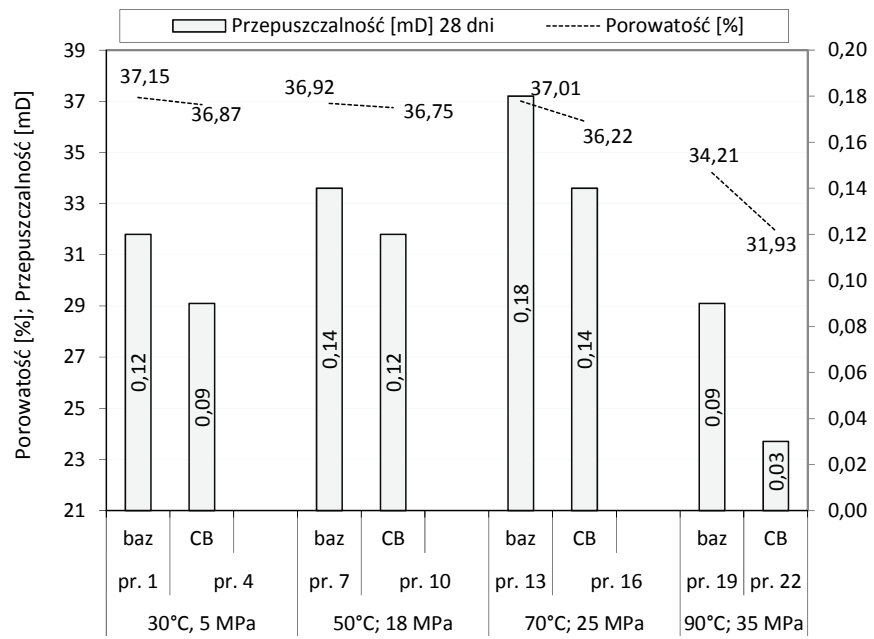

Rys. 9. Zestawienie wyników porowatości i przepuszczalności badanych próbek 
Na podstawie przeprowadzonej analizy wpływu dodatku szkła wodnego sodowego CB75 na poprawę parametrów technologicznych zaczynów cementowych potwierdzona została wcześniej postawiona teza. Dodatek szkła wodnego sodowego powoduje znaczną poprawę parametrów świeżego i stwardniałego zaczynu cementowego. Uzyskano wzrost parametrów reologicznych przy jednoczesnej poprawie stabilności sedymentacyjnej płynnego zaczynu. Zastosowanie dodatku szkła wodnego sodowego skutkowało wyeliminowaniem wartości odstoju wody oraz znacznym obniżeniem filtracji zaczynu, co jest wymagane przy projektowaniu zaczynów zarówno do otworów kierunkowych i horyzontalnych, jak również przeznaczonych do uszczelniania kolumn rur okładzinowych posadowionych na obszarze o podwyższonym ryzyku migracji gazu. Szkło wodne sodo- we powoduje skrócenie czasu gęstnienia zaczynu, co należy mieć na uwadze, wykorzystując odpowiednie ilości dodatków opóźniających czas gęstnienia. Ponadto stosowanie wodnej dyspersji krzemianu sodu wpływa korzystnie na poprawę parametrów mechanicznych tworzącego się płaszcza cementowego. Uzyskano wzrost zarówno wytrzymałości na ściskanie, jak również wzrosły wartości przyczepności płaszcza cementowego do formacji skalnej i do rur stalowych. Dodatkowo mikrostruktura płaszcza cementowego (opisywana w niniejszym cyklu badawczym parametrami takimi jak porowatość i przepuszczalność) została znacznie doszczelniona, co objawiło się obniżeniem wartości wspomnianych parametrów. Stosowanie dodatku szkła wodnego jest korzystne ze względu na możliwość uzyskania skompaktowanej i nieprzepuszczalnej mikrostruktury płaszcza cementowego.

\section{Wnioski}

Na podstawie zrealizowanych prac badawczych, których celem było określeniem możliwości poprawy parametrów technologicznych zaczynów cementowych poprzez zastosowanie dodatku wodnej dyspersji krzemianów sodu, wyciągnięto następujące wnioski:

- wprowadzenie szkła wodnego do receptury zaczynu cementowego zawierającego różne dodatki i domieszki wymaga przeprowadzenia badań dla konkretnego składu i warunków otworopodobnych;

- dodatek szkła wodnego powoduje nieznaczne obniżenie wartości gęstości zaczynu w porównaniu z odpowiadającymi próbkami kontrolnymi nieposiadającymi tego dodatku;

- szkło wodne sodowe powoduje niewielki wzrost granicy płynięcia, a jednocześnie pozwala na uzyskanie wymaganej stabilności sedymentacyjnej zaczynu cementowego. Receptury zaczynów z dodatkiem szkła wodnego nie sedymentują wskutek działających sił grawitacji;
- zastosowanie szkła wodnego sodowego powoduje wyeliminowanie powstawania odstoju wody oraz znaczne obniżenie wartości filtracji;

- modyfikacja zaczynu cementowego z dodatkiem szkła wodnego sodowego skutkuje skróceniem czasu gęstnienia zaczynu podczas badania w konsystometrze HTHP. Należy mieć powyższe na uwadze i zastosować odpowiednią ilość środka opóźniającego gęstnienie zaczynu;

- analizując parametry mechaniczne zaczynów cementowych z dodatkiem szkła wodnego, zaobserwowano znaczną poprawę parametrów mechanicznych i fizykomechanicznych (wytrzymałości na ściskanie, przyczepności do formacji skalnej, przyczepności do rur stalowych);

- stosowanie dodatku szkła wodnego w zaczynach cementowych skutkuje doszczelnieniem struktury stwardniałego zaczynu cementowego, objawiającym się obniżeniem porowatości oraz przepuszczalności dla gazu badanych próbek.

Prosimy cytować jako: Nafta-Gaz 2017, nr 10, s. 750-759, DOI: 10.18668/NG.2017.10.04

Artykuł nadesłano do Redakcji 26.04.2017 r. Zatwierdzono do druku 22.06.2017 r.

Artykuł powstał na podstawie pracy badawczej pt.: Analiza możliwości poprawy stabilności sedymentacyjnej zaczynów cementowych - praca INiG - PIB na zlecenie MNiSW; nr zlecenia: 36/KW/16, nr archiwalny: DK-4100/36/16.

\section{Literatura}

[1] Aguilera R., Artindale J.S., Cordell G., Ng M.C., Nicholl G.W., Runions G.A.: Horizontal Wells. Gulf Publishing Company, Houston 1991.

[2] Armessen P., Jourdan A.P., Mariotti Ch.: Horizontal drilling gas negative and positive factors. PennWell Publishing Comp. 1988.

[3] Bensted J.: Oilwell Cements. Cement Wapno Beton 2002, nr 6, s. 249-265.

[4] Bensted J., Smith J.R.: Cementy wiertnicze historycznej perspektywy. Cz. 6. Cement Wapno Beton 2008, nr 3, s. 124-135.

[5] Chatterji S.: On the properties of freshly made Portland cement paste. Part 2. Sedimentation and strength of flocculation. Cement and Concrete Research 1988.

[6] Dębińska E.: Ocena dziatania dodatków opóźniających czas wiązania zaczynów cementowych na podstawie badań laboratoryjnych. Nafta-Gaz 2012, nr 4, s. 225-232. 
[7] Dębińska E.: Wyznaczanie statycznej wytrzymałości strukturalnej $i$ wczesnej wytrzymatości mechanicznej zaczynów cementowych. Nafta-Gaz, 2013, nr 2, s. 134-142.

[8] Dohnalik M., Zalewska J.: Korelacja wyników laboratoryjnych uzyskanych metoda rentgenowskiej mikrotomografii, jadrowego rezonansu magnetycznego i porozymetrii rtęciowej. Nafta-Gaz 2013, nr 10, s. 735-743.

[9] Gawlik P., Szymczak M.: Migracje gazowe w przestrzeniach międzyrurowych otworów realizowanych na przedgórzu Karpat. Nafta-Gaz 2006, nr 7-8, s. 349-358.

[10] Kątna Z. i in.: Badania modelowe wpływu odstoju wody, sedymentacji i poczatkowego skurczu zaczynu cementowego na jakość uszczelniania rur $w$ otworach odchylonych od pionu i poziomych $w$ temperaturach do $85^{\circ} \mathrm{C}$. Praca naukowo-badawcza INiG, Kraków 1997.

[11] Kremieniewski M., Rzepka M., Dębińska E.: Statyczna wytrzymatość strukturalna zaczynów przeznaczonych do uszczelniania otworów o podwyższonym ryzyku występowania migracji gazu. Nafta-Gaz 2014, nr 9, s. 608-616.

[12] Kremieniewski M., Rzepka M., Stryczek S., Wiśniowski R., Kotwica Ł., Złotkowski A.: Korelacja przepuszczalności i parametrów opisujących strukturę stwardniałych zaczynów cementowych stosowanych do uszczelniania otworów $w$ rejonie Basenu Pomorskiego. Nafta-Gaz 2015, nr 10, s. 737-746, DOI: 10.18668/NG2015.10.04.

[13] Kremieniewski M., Rzepka M.: Badania zaczynów cementowych przeznaczonych do uszczelniania otworów wiertniczych. Wiadomości Naftowe i Gazownicze 2012, nr 4, s. 9-13.

[14] Kremieniewski M., Stryczek S., Kotwica Ł.: Zmiany w mikrostrukturze plaszcza cementowego w zależności od warunków hydratacji zaczynu. Nafta-Gaz 2014, nr 12, s. 918-926.

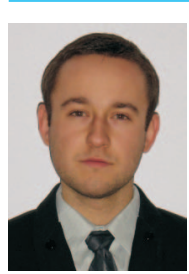

Dr inż. Marcin KREMIENIEWSKI

Adiunkt w Zakładzie Technologii Wiercenia.

Instytut Nafty i Gazu - Państwowy Instytut Badawczy

ul. Lubicz 25 A

31-503 Kraków

E-mail: marcin.kremieniewski@inig.pl
[15] McNaught A.D., Wilkinson A.: IUPAC. Compendium of Chemical Terminology (Gold Book). Wyd. 2. Oksford: Blackwell Scientific Publications, 1997. Wersja internetowa: Nic M., Jirat J., Kosata B.: Colloidal dispersion (ang.), aktualizowana przez Jenkins A., DOI: 10.1351/goldbook.C01174.

[16] Nelson E.B.: Cementowanie otworów wiertniczych. Schlumberger Edicational Serwice, Houston, Texas, USA, 1990.

[17] Praca zbiorowa: Nowe aplikacje w zakresie udostepniania i eksploatacji złóż węglowodorów otworami kierunkowymi i poziomymi. Prace INiG nr 152, Kraków 2008.

[18] Praca zbiorowa: Rzeczpospolita łupkowa. Studium wiedzy o gazie z formacji łupkowych. Prace INiG nr 183, Kraków 2012.

[19] Rzepka M., Kremieniewski M., Dębińska E.: Zaczyny cementowe przeznaczone do uszczelniania eksploatacyjnych kolumn rur okładzinowych na Niżu Polskim. Nafta-Gaz 2012, nr 8, s. 512-522.

[20] Rzepka M., Stryczek S.: Laboratoryjne metody określania parametrów technologicznych świeżych zaczynów uszczelniajacych przed zabiegiem zwiazanym z procesem uszczelniania kolumn rur okładzinowych w otworach wiertniczych. Wiertnictwo, Nafta, Gaz 2008, t. 25, z. 2, s. 625-636.

[21] Stryczek S., Wiśniowski R., Gonet A., Złotkowski A.: The influence of time of rheological parameters of fresh cement slurries. AGH Drilling, Oil, Gas 2014, vol. 31, s. 123-133.

[22] Stryczek S., Wiśniowski R., Kotwica Ł., Złotkowski A., Rzepka M., Kremieniewski M., Skrzypaszek K.: Analysis of technological parameters of cementing slurries for horizontal casing works in Pomeranian Basin. AGH Drilling, Oil, Gas 2015, vol. 32, nr 2, s. 431-442.

[23] Zima G.: Nowy rozklad pluczki wiertniczej do zastosowania w warunkach HTHP. Nafta-Gaz 2015, nr 8, s. 556-564.

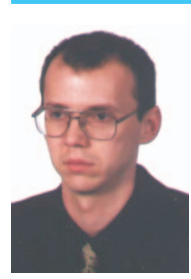

Dr inż. Marcin RZEPKA

Kierownik Laboratorium Zaczynów Uszczelniających w Zakładzie Technologii Wiercenia. Instytut Nafty i Gazu - Państwowy Instytut Badawczy ul. Lubicz 25 A

31-503 Kraków

E-mail: marcin.rzepka@inig.pl 